

\title{
A Perusal of Managers' Optimism Pursuant to the Rate of Hormones in Blood
}

\section{Maryam Nouraei}

$\mathrm{PhD}$ Candidate, Department of Accounting, Sanandaj Branch, Islamic Azad University, Sanandaj, Iran. (Email: Nouraeimaryam7@gmail.com)

\section{Ataalah Mohammadi Molgharni*}

*Corresponding Author, Assistant Prof., Department of Accounting, Sanandaj Branch, Islamic Azad University, Sanandaj, Iran. (Email: mohammadiata98@gmail.com)

\section{Iraj Noravesh}

Prof., Department of Accounting, Faculty of Management, University of Tehran, Tehran, Iran. (Email: inoravesh@ut.ac.ir)

\section{Kaveh Bahman Pour}

Assistant Prof., Department of Nursing and Midwifery, Sanandaj Branch, Islamic Azad University, Sanandaj, Iran. (Email: kaveh_hpt@hotmail.com)

Document Type: Original Article

Received: 2020/11/03

Accepted: 2020/12/27
2020, Vol. 4, No. 4. 28-43

Published: 2020/12/27

\begin{abstract}
The objective of the current survey was to excavate the effect of the rate of hormones in the blood, age, and gender on the financial behavior of managers. Also, preparing and propounding the neurofinance model of financial behaviors that have generated anomalies such as optimism in the market is other intentions of this study. This research has been operated with an inductive approach and experimentally in a one-time period in a statistical population consisting of 37 male and female managers with an average age of 25-60 years. The amounts of the testosterone, free testosterone, cortisol T3, T4, and TSH were deliberate in a medical diagnostic laboratory with a blood test. Managers' optimism data were accumulated with a standardized questionnaire straight away afterward receiving the blood sample. The prepared data were analyzed with SPSS and LISREL and RSM software. The outcomes demonstrated that age has a significant inverse relationship with optimism.
\end{abstract}


Free Testosterone; T4 and testosterone play an inverse role in optimism augmenting. Cortisol and T3 are straightly related to optimism. Also, financial behavior is further related to the dimension of optimism in women than men, and with growing older, optimism decreases. The significant effect of testosterone and cortisol, age and gender on optimism, confirmed the effect of these hormones on the financial behavior in other studies. The effect of testosterone and thyroid hormones on optimism was considered in this survey for the first time.

Keywords: Financial Behavior, Hormone, Neuro Finance, Optimism.

DOI: $10.30699 / \mathrm{ijf} .2020 .121481$

Publisher: Iran Finance Association

Copyright: author(s)

Type of License: Creative Commons License (CC-BY 4.0)

\section{Introduction}

Inspecting the neurological occasion of financial demeanors is lesser-known objectivity. The principal question of this inquiry is whether it is possible to prepare a model for managers' financial behaviors relying on brain perception and the rate of hormones in the blood. Numerous studies have shown the effects of testosterone and cortisol on financial behavior(Coates \& Herbert, 2008; Cueva et al., 2015).

Howsoever these hormones have mighty effects on decision-making by alone; there is furthermore synergy between hormones. Both are steroids, meaning that the cellular action they accomplish on neurons is so homological that they both act on receptor-binding steroid-binding molecules inside the cell, which are reasonable for each hormone but are not quite specific. The lifespan of these two steroids is different. Aging affects testosterone changes, but cortisol is less affected by age.

Traditional financial theories are constructed on the efficient market of Fama (1998), which elucidated individuals are not market opponents; All information is logically distinguished and proclaimed in the prices, and there is no opportunity for arbitrage(Miendlarzewska, Kometer, \& Preuschoff, 2019). The paradigm that prevails in classical (modern financial finance) theories is based on maximizing the expected utility and risk aversion, while experimental studies of the real world, on the other hand, have drawn much criticism in recent years to modern financial theories and the assumption of the rational human. (Fernandes, Lynch, \& Netemeyer, 2014). Anyway, Decision-makers and managers perceive the formation of bubbles in the capital and housing markets as a kind of anomaly in economic and financial theories. Plenty of 
studies have discussed the neural basis of financial and asset bubbles; price bubbles in the stock, investors' optimistic behavior, housing, currency, and gold markets indicate that managers do not always make rational financial decisions. Then, by accepting behavioral prejudices such as overconfidence, optimism and pessimism of managers, behavioral finance was used as a bridge between economics, psychology and neuroscience to examine the reasons for the deviation of people's financial decision-making and the conditions of the efficient market violation(Delcey, 2018).

The insights gained from behavioral biases such as managers' optimism and their influence on financial theories have led to a step forward in research. For example, research into why these prejudices occur in the brain and whether a neurological study can improve existing financial models. People's financial behaviors in the market are the most important reasons for changes in the economy and finances. Neurofinance is an emerging field that identifies the causes of financial behaviors, such as managers' optimism and the creation of bubbles and irrational decisions, by recognizing the brain(Coates \& Herbert, 2008; Daw, Gershman, Seymour, Dayan, \& Dolan, 2011; Simonsen, 2013).

Neurofinance tries to percept the reasons for managers' financial decisions by relying on their physical characteristics. The levels of some hormones, such as testosterone and cortisol, have been studied in many investigations on risktaking, optimism, and other financial behaviors(Frydman \& Camerer, 2016; Stanton, 2016; Stenstrom \& Saad, 2011). Also, Neurofinance uses Magnetic Resonance Imaging function (fMRI), heart rate measuring and eye movements to provide evidence that explains the differences in managers' financial decision-making(Ascher, Silva, Veiga, \& Souza, 2016a; Frydman \& Camerer, 2016).

The aim of current research is to provide an analysis and basics in the field of Neurofinance as well as to understand the relationship between Neurofinance and managers' behavior according to the rate of hormones. In the following, the theoretical foundations of behavioral finance and Neurofinance and the abnormalities of efficient market hypothesis and expected utility and perspective theory are discussed.

Then the research question, the research method, the conclusion and the discussion are presented. Blood tests were taken from managers to determine the amount of the hormones. The code of ethics for human sampling was obtained from the University of Medical Sciences. The optimism of thirtyseven managers was compiled with financial questionnaires which its validity and reliability were assessed by factor analysis and Cronbach's test, and finally, 
the ultimate model will be presented in the analysis and conclusion section.

\section{Literature Review}

In the first years of the 1980s, a lot of scholars started to detect realities in the field of the aggregate stock market that was hard to illustrate with this rational view of the globe. For example, a classic paper that is often cited as the onset of behavioral finance showed that stock prices surge too much to be justified by a rational theory of stock valuation (Frydman \& Camerer, 2016). This set of anomalous facts only grew more powerful. Then, More financial economists started to create new mathematical models where investor behavior was governed by increasingly realistic psychological powers(Coates \& Herbert, 2008).

There was significant progress over the past 30 years in testing behavioral models of finance, often combining platforms and methods from the cognitive psychology of judgment and choice. research in financial decision making recently has started to use emerging sources of data such as fMRI and logins to online trading brokerages. In the rest of this review, these studies outline several of the advances that have been made in these researches areas and speculate on future directions where cognitive science can play an important role in advancing the understanding of financial decision making(Ascher et al., 2016a; Stanton, 2017).

Ascher et al (2016) introduce some of the neurological tools used in neurofinance including Functional Magnetic Response Imaging (fMRI), Electro Encephalo Graphy (EEG), Magneto Encephalo Graphy (Meg), Transcranial Magnetic Stimulation (TMS), Positron Emission Tomography (EMS) Positron Emission Tomography (PET). Kuehne and Knutson (2005) using (fMRI) showed that profit and loss and relative market values affect different areas of the brain.

According to Jinda and Bahl (2016), brain structure and levels of hormones have different effects on investor behavior. Serotonin levels fall when expectations are unfinished, such as investment losses. Such situations lead to depression and anxiety and loss of enthusiasm among investors. Under these emotions, investors make inappropriate decisions that multiple losses and increase transaction costs. Risk aversion may be due to decreased serotonin levels. Dopamine is a spattered chemical that is released from the brain when people feel pleasure. When the unexpected gain is made, the same hormone is released and when the unexpected loss is made to the investor, its secretion is completely stopped. Dopamine causes herd behavior, overconfidence, and 
optimism in investors(Jinda \& Bahl, 2016).

Milam, Slaughter, Verma, McConnell (2014) examined the effect of cortisol on optimism; the method of measuring cortisol was based on the hair samples of the participants in the study. The results showed that cortisol rate had a significant inverse relationship with optimism [20]. The results of this study were in accordance with the findings of Milam et al; Herbert and Coates. Herbert and Coates (2008) found that traders under pressure from market fluctuations had a $68 \%$ increase in the average level of cortisol. In addition to examining the role of cortisol in traders, Coates and Herbert also measured the rates of testosterone, the androgen hormone. The authors found that people with higher average levels of the hormone tended to make more profit in financial transactions(Milam, Slaughter, Verma, \& Mcconnell, 2014).

Stenstrom et al. (2011), with the participation of 154 volunteers, assessed the risk-taking of individuals. The results showed that people with high testosterone levels were more likely to be at risk than people with low testosterone. Although no gender differences in risk or risk aversion have been observed in the current survey, most studies have concluded that men are less risk-averse than women(Stenstrom \& Saad, 2011). In the present study, female gender was more optimistic than male; the two hormones testosterone and free testosterone have the opposite effect on optimism, meaning that those with higher testosterone and free testosterone have less optimism.

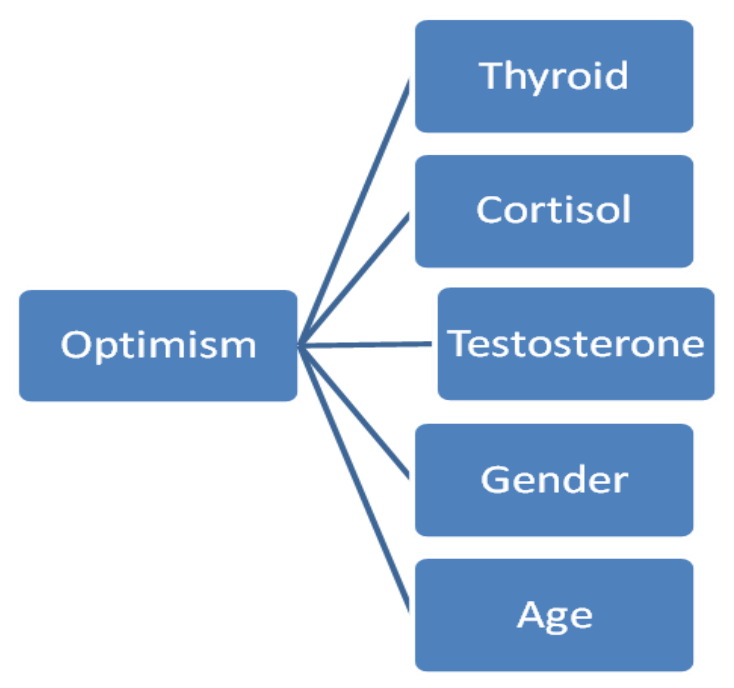

Figure 1. Conceptual model 


\section{Methodology}

The current research is developmental-applied in terms of purpose and based on nature, the method of work is experimental implementation and the causal type and in terms of data collection is field and laboratory research. The research method is inductive in terms of execution logic and cross-sectional in terms of time and is qualitative and quantitative in terms of nature and quantitative in terms of data transfer to the software.

The purpose of this study is to provide a model for identifying optimism with a neurofinance approach and seeks to determine a framework that goes beyond behavioral financial theory to provide a model for managers' behavior with respect to the impact of hormonal changes. Data in this study were collected in the field and library through a questionnaire and medical tests.

Hormone changes in this study mean the difference in hormone levels between each of the participants in the study. Hormone levels and rates were measured by participants' blood tests. The blood test was performed by DiaSorin kit and after collecting all the tests in a specialized laboratory environment, and then it was delivered to the analysis department. Data analysis was performed by a Chemiluminescence device, which is one of the most accurate hormones measuring devices.

The results obtained in the previous section, which shows the rate of hormone units in the blood of participants, were recorded in Excel software for statistical analysis of hormone levels in participants and financial behaviors. Questionnaires were completed immediately after the blood test by the study participants.

In the first place, the face and content validity of the research questionnaire was approved by the supervisor and expert professors, which shows sufficient and appropriate reliability of the questionnaire. Studies have stated different values for accepting items in factor analysis, but there is a consensus for the value of 0.50 , so statements that the agent could not explain above 0.50 of their variations should be adjusted or eliminated. Therefore, the minimum acceptable rate for accepting items in the underlying factors was considered 0.50 . The reliability of the questionnaire was 0.91 using Cronbach's alpha. The indicator indicates acceptable reliability for the research questionnaire because it is more than 0.70 . To collect the required information for the theoretical foundations of the research and to form a conceptual model, the latest scientific articles and books related to behavioral and neurological finance and for hormonal data, the blood test was used. It was used to identify 
the research variables according to(Herbert, 2018; Kamiya, Kim, \& Park, 2019; Nadler \& Zak, 2016; Peterson, 2011) models. To test hormones, testosterone, free testosterone, and cortisol were added to the hormones according to previous research models and thyroid hormones (T3, T4, and TSH) to expand the scope of the study. The statistical population of the study included men and women financial managers of banks and public and private institutions in the age range of 25-60 years. After reviewing the questionnaire by experts and faculty members, the number of questions and items was determined. The sampling method was available for sampling. Some of the main characteristics of managers were as follows: to be involved with the issue in question, to be in constant contact with financial decision making, and to be motivated to participate in the testing process. For this study, we had 42 participants, 14 women and 28 men, during which seven people, including six men and one woman, were eliminated from all analyzes due to testosterone levels above the standard level and deviations above the mean level. Statistical data of the remaining 35 people were analyzed.

Table 1. Confirmatory factor analysis of optimism and pessimism

\begin{tabular}{|c|c|c|l|}
\hline Factor load & item & Factor load & item \\
\hline .66 & 8. & .66 & 1. \\
\hline .65 & 9. & .44 & 2. \\
\hline .60 & 10. & .57 & 3. \\
\hline .57 & 11. & .49 & 4. \\
\hline .48 & 12. & .5 & 5. \\
\hline .52 & 13. & .46 & 6. \\
\hline .43 & 14. & .7 & 7. \\
\hline
\end{tabular}

As shown in Table 1, 5 items were not approved in terms of factor load, which were eliminated in the final research questionnaire. Participants donated a blood sample for two days in the morning by presenting a letter of introduction free of charge. Sample tests were taken at 8 a.m. After taking the samples, the laboratory analyzed the rates of hormones in the blood of the participants and provided the results to the researchers after two weeks.

Table 2. Research questions

\begin{tabular}{|c|}
\hline Does cortisol affect optimism? \\
\hline Do Thyroid Hormones Affect Optimism? \\
\hline Do testosterone hormones affect optimism? \\
\hline Do Age and Gender Affect Optimism? \\
\hline
\end{tabular}




\section{Research Findings}

\section{Analysis in SPSS}

1.Fit multiple regression models for optimism dimension

Table 3. Model Summary

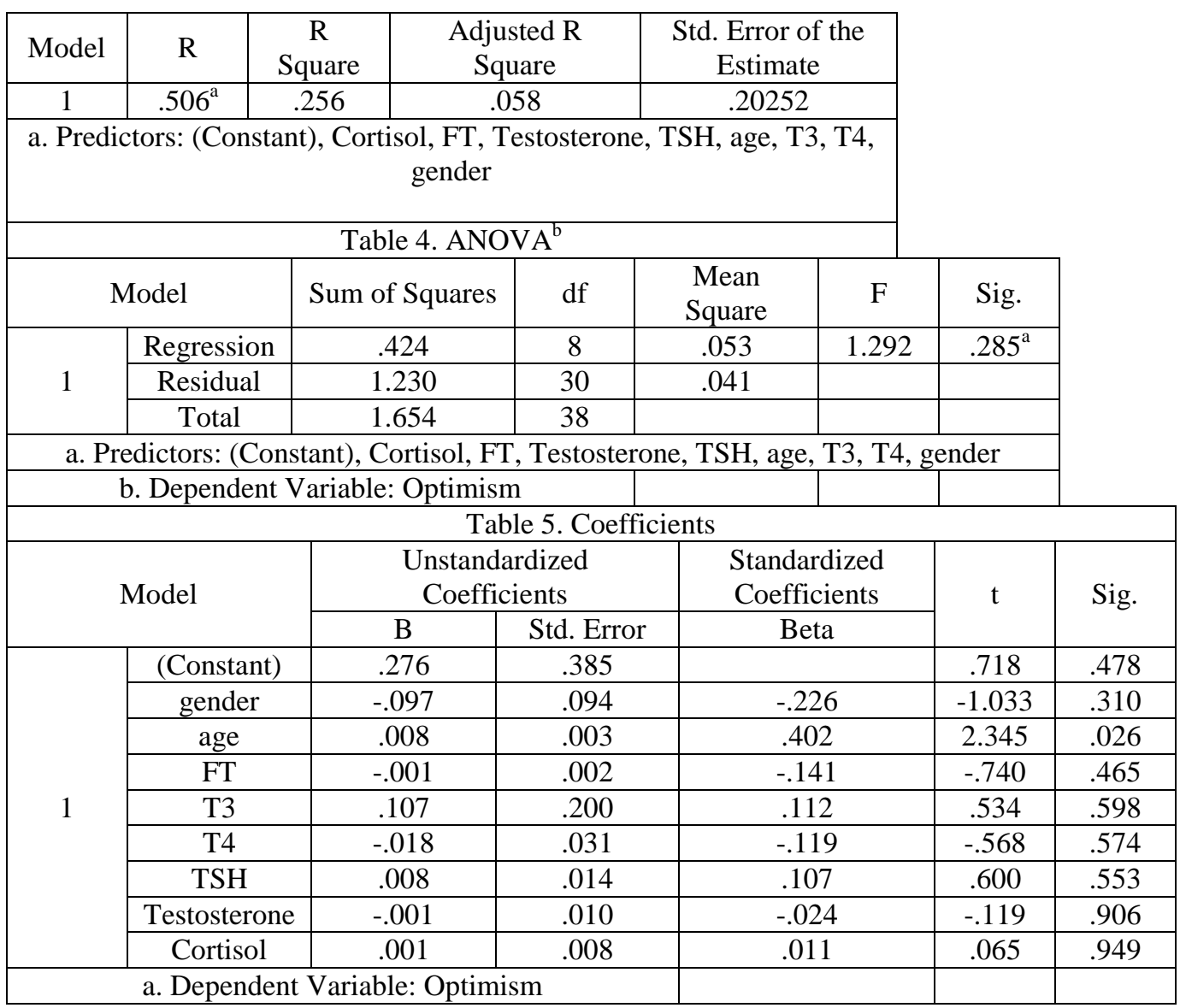

Multivariate regression was used for statistical analysis of optimism; the results are as follows:

According to the results of the first table, the coefficient of determination of this multiple regression model is $26 \%$. In other words, 8 independent gender variables; Age; Free testosterone; T3; T4; TSH; Testosterone and cortisol set a $26 \%$ overall optimism. The ANOVA regression table shows that the control level of this model is not significant $(\mathrm{P}>0.05)$. Also, according to the second table of the regression model for the optimistic dimension, and according to the coefficients of the model, it is as follows: 
Optimism $=0.276-0.097$ gender -0.008 age $-0.001 \mathrm{FT}+0.107 \mathrm{~T} 3-0.018 \mathrm{~T} 4+$ 0.008TSH - 0.001Testosterone + 0.001Cortisol+ Error

Based on the results of the coefficients in the standardized age mode; Free testosterone; T4 and testosterone play an inverse role in increasing optimism; means, optimism decreases as they increase. Also, financial behavior is related to the dimension of optimism in women more than men, and of course, with age, optimism in financial behavior decreases.

Free testosterone (with a ratio of 0.740 ) and cortisol (with a ratio of 0.065 ) have the most and least ratios in predicting the dimension of optimism respectively. However, based on the results of the T-test, the only age regression coefficient of the respondents on optimism in the model was significant $(\mathrm{P}<0.05)$.

\section{Analysis in Lisrel}



Figure 2. Final model 
Test data were re-prepared in LISREL software. The results and coefficients obtained indicate the effect of hormone rates on optimism.

\section{Analysis in RSM}

Table6. ANOVA for Reduced Quadratic model

\begin{tabular}{|c|c|c|c|c|c|c|}
\hline Source & Sum of Squares & df & Mean Square & F-value & $\mathrm{p}$-value & \\
\hline Model & 1.08 & 15 & 0.0718 & 2.83 & 0.0172 & significant \\
\hline A-Free Testosterone & 0.3603 & 1 & 0.3603 & 14.20 & 0.0013 & \\
\hline B-T3 & 0.0006 & 1 & 0.0006 & 0.0235 & 0.8797 & \\
\hline C-T4 & 0.3682 & 1 & 0.3682 & 14.51 & 0.0012 & \\
\hline D-T.S.H & 0.0518 & 1 & 0.0518 & 2.04 & 0.1694 & \\
\hline E-Testosterone & 0.2475 & 1 & 0.2475 & 9.75 & 0.0056 & \\
\hline F-Cortisol 8 A.M & 0.0649 & 1 & 0.0649 & 2.56 & 0.1262 & \\
\hline $\mathrm{AB}$ & 0.1197 & 1 & 0.1197 & 4.72 & 0.0427 & \\
\hline $\mathrm{AC}$ & 0.4058 & 1 & 0.4058 & 15.99 & 0.0008 & \\
\hline $\mathrm{AF}$ & 0.1255 & 1 & 0.1255 & 4.95 & 0.0384 & \\
\hline $\mathrm{BC}$ & 0.3742 & 1 & 0.3742 & 14.75 & 0.0011 & \\
\hline $\mathrm{BD}$ & 0.2037 & 1 & 0.2037 & 8.03 & 0.0106 & \\
\hline $\mathrm{CE}$ & 0.2987 & 1 & 0.2987 & 11.77 & 0.0028 & \\
\hline EF & 0.1335 & 1 & 0.1335 & 5.26 & 0.0334 & \\
\hline $\mathrm{A}^{2}$ & 0.2240 & 1 & 0.2240 & 8.83 & 0.0078 & \\
\hline $\mathrm{B}^{2}$ & 0.1203 & 1 & 0.1203 & 4.74 & 0.0423 & \\
\hline Residual & 0.4821 & 19 & 0.0254 & & & \\
\hline Cor Total & 1.56 & 34 & & & & \\
\hline
\end{tabular}

This table examines the effect of each hormone alone or when they come together on the optimistic response. In the ANOVA table, the synergy of hormones that had no significant effect was eliminated. A2, C2, D2, means what effect do hormones have in higher amounts. The second column is the sum of the squares, and in the next column, the degree of freedom is one for each individual item, and for the model, the sum of the items. The next column is the mean of the squares. This means, the sum of the squares, and the degree of freedom are used to calculate the F-Value and the P-Value. The F-value indicates how much each hormone affects the average optimism. The higher the $\mathrm{F}$ value, the greater the effect. For example, $\mathrm{AC}=15.99$ have more value than other hormones, so it has a much greater effect on the average optimism. The P-value indicates that hormones have a significant effect on the mean of optimism. The base value of the model is 0.0028 . Because the base value of the model is less than 0.005 , so it is significant. In addition, $0.8797=\mathrm{C}-\mathrm{T} 3$ is greater than 0.05 , i.e. its changes are not significant, but it came in the model. Because the combination of these two $\mathrm{BC}$ and $\mathrm{AC}$ are significant, so each of 
these two must be in the model, so $\mathrm{C}$ was reported in the model.

Table7. Fit Statistics

\begin{tabular}{|l|l|l|l|l|}
\hline Std. Dev. & 0.1593 & & R $^{2}$ & 0.6908 \\
\hline Mean & 0.5714 & Adjusted R & 0.4467 \\
\hline
\end{tabular}

The statistical appropriateness table shows that hormones have an effect on the average optimism with a coefficient of determination of / 6908 and a coefficient of determination of / 4467. In RSM analysis, the interaction of hormones was also measured and presented in the final model. Positive coefficients indicate the direct effect of increasing the hormone with the average of optimism and negative coefficients indicate the opposite effect of increasing the hormone with the average of optimism.

\section{Final Equation in Terms of Actual Factors}

\begin{tabular}{|l|l|}
\hline Average optimism & $=$ \\
\hline-1.53761 & \\
\hline-0.218375 & Free Testosterone \\
\hline-1.76875 & T3 \\
\hline+0.950640 & T4 \\
\hline-0.484876 & T.S.H \\
\hline+0.780971 & Testosterone \\
\hline-0.016601 & Cortisol 8 A.M \\
\hline-0.073185 & Free Testosterone $*$ T3 \\
\hline+0.026070 & Free Testosterone $*$ T4 \\
\hline+0.003557 & Free Testosterone $*$ Cortisol 8 A.M \\
\hline-0.660149 & T3 $*$ T4 \\
\hline+0.346571 & T3 $*$ T.S.H \\
\hline-0.080740 & T4 $*$ Testosterone \\
\hline-0.009989 & Testosterone $*$ Cortisol 8 A.M \\
\hline+0.003772 & Free Testostrone \\
\hline+2.35805 & T32 \\
\hline
\end{tabular}

In this equation, positive coefficients had a positive and direct effect on optimism and negative coefficients had an inverse effect on optimism. Because the P-Value model was less than 0.05, the change in hormone levels had a significant effect on optimism. E (testosterone) has a negative coefficient, which means the higher the level of testosterone, the lower the average optimism. Also, the interaction of free testosterone and $\mathrm{T} 3$ (AB), the interaction of $\mathrm{T} 3$ and $\mathrm{T} 4$ (BC), and the interaction of free testosterone and cortisol (EF) had a negative coefficient, which means the effect on optimism was reversed. As the levels of these hormones increase separately or together, optimism decreases. 


\section{Conclusion and Discussion}

What effect do hormonal changes have on managers' optimism?

The results of regression analysis in SPSS software showed that there is a significant relationship between hormone levels, age, and gender with managers' optimism. There is a direct and significant relationship with increasing hormone levels predicting optimistic behavior. Managers with higher levels of T3, cortisol, and TSH had more optimistic behavior than managers with lower levels of T3, cortisol, and TSH. Also, older managers were less optimistic than younger managers. The inverse relationship between age and the negative coefficient is shown in the second table of the regression model. Also, female managers are more optimistic than male managers. The results of response level methodology analysis showed that free testosterone and testosterone cortisol have an inverse relationship with optimism and also on the interaction of free testosterone hormones V3, T4, and T3 and testosterone and T4 have a negative relationship with optimism. The increase in T3 level showed a direct relationship with managers' optimism. Also, hormone levels are different in men and women. It was also shown that free testosterone levels are higher in men than in women. Hormone levels in men and women also decrease with age.

Comparison of the results of the two analyzes shows that SPSS software shows the relationship between $\mathrm{T} 3$ and cortisol with optimism with a positive coefficient and the RSM software, which is independent for models with several variables, shows T3 and cortisol with a negative coefficient. Analysis of the RSM shows the interaction of hormones and also examines the increase in the rate of hormones. The analysis of this research confirms the results of the studies of (Ascher et al., 2016a; FRYDMAN, BARBERIS, CAMERER, BOSSAERTS, \& RANGEL, 2014; Frydman \& Camerer, 2016). In this study, women were more optimistic than men; Both testosterone and free testosterone have the opposite effect on optimism, meaning that those with higher testosterone and free testosterone have less optimism.

The results of this part of the test are consistent with the studies of Cueva et al (2015); Stanton (2017); Milam et al. (2014) as well as coats and Herbert (2008).

Many studies have discussed the optimistic basis of the asset bubble. These results are based on the theory of the expected utility model, and generally, show how neural data can be tested in experimental models based on the neurological analysis of investor behavior is useful (Ascher, Silva, Veiga, 
\& Souza, 2016b; Frydman \& Camerer, 2016). The answers to the questions in this research can be used to identify the neural basis in market conditions, inflation, and recession to examine managers' financial decisions for managers.

The market simulation was used to examine financial behaviors and financial decisions and the effect of hormones in most of the articles reviewed in this study(FRYDMAN et al., 2014; Kamiya et al., 2019; Peterson, 2011). It is suggested that the models of these articles be used for future research. It is suggested that the domain of hormones be changed in future research; for example, the hormones progesterone, insulin, and estrogen can be used. Spatial and temporal territory, statistical population, and more samples should be studied.

Note:

This research is taken from the doctoral dissertation of Islamic Azad University, Sanandaj Branch (Code 9806). The authors of the article need to thank the cooperation and assistance of the Islamic Azad University, the staff of the Kermanshah Reference Laboratory, and all the loved ones who have helped in this research.

Funding: This research received no external funding.

\section{References}

Ascher, D., Silva, W., Veiga, C. P. da, \& Souza, A. (2016b). Neurofinance : a systematic review about a new way of looking the financial decision-making. European Journal of Scientific Research, 141(4), 407-426.

Coates, J. M., \& Herbert, J. (2008). Endogenous steroids and financial risktaking on a London trading floor. Proceedings of the National Academy of Sciences of the United States of America, 105(16), 6167-6172. https://doi.org/10.1073/pnas.0704025105

Cueva, C., Roberts, R. E., Spencer, T., Rani, N., Tempest, M., Tobler, P. N., ... Rustichini, A. (2015). Cortisol and testosterone increase financial risk-taking and may destabilize markets. Scientific Reports, 5, 1-16. https://doi.org/10.1038/srep11206

Daw, N. D., Gershman, S. J., Seymour, B., Dayan, P., \& Dolan, R. J. (2011). Model-based influences on humans' choices and striatal prediction errors. Neuron, 69(6), 1204-1215. https://doi.org/10.1016/j.neuron.2011.02.027

Delcey, T. (2018). Efficient Market Hypothesis, Eugene Fama and Paul Samuelson: A reevaluation. Hal, 1-26. 
Fernandes, D., Lynch, J. G., \& Netemeyer, R. G. (2014). Financial literacy, financial education, and downstream financial behaviors. Management Science, 60(8), 1861-1883. https://doi.org/10.1287/mnsc.2013.1849

FRYDMAN, C., BARBERIS, N., CAMERER, C., BOSSAERTS, P., \& RANGEL, A. (2014). Using Neural Data to Test a Theory of Investor Behavior: An Application to Realization Utility. The Journal of Finance, 69(2), 907-946. https://doi.org/10.1111/jofi.12126

Frydman, C., \& Camerer, C. F. (2016). The Psychology and Neuroscience of Financial Decision Making. Trends in Cognitive Sciences, 20(9), 661-675. https://doi.org/10.1016/j.tics.2016.07.003

Herbert, J. (2018, May 16). Testosterone, cortisol and financial risk-taking. $\begin{array}{llll}\text { Frontiers in Behavioral Neuroscience, } & \text { Vol. } & 12 .\end{array}$ https://doi.org/10.3389/fnbeh.2018.00101

Jinda, P., \& Bahl, S. (2016). The New Era of Finance: Neurofinance and Investment behavior. In Mullana Research Scholar International Journal of Research in Finance and Marketing (IJRFM) (Vol. 6). Retrieved from http://euroasiapub.org/current.phphttp://www.euroasiapub.org

Kamiya, S., Kim, Y. H. A., \& Park, S. (2019). The face of risk: CEO facial masculinity and firm risk. European Financial Management, 25(2), 239-270. https://doi.org/10.1111/eufm.12175

Miendlarzewska, E. A., Kometer, M., \& Preuschoff, K. (2019). Neurofinance. Organizational Research Methods, 22(1), 196-222. https://doi.org/10.1177/1094428117730891

Milam, J., Slaughter, R., Verma, G., \& Mcconnell, R. (2014). Hair Cortisol, Perceived Stress and Dispositional Optimism: A Pilot Study among Adolescents. https://doi.org/10.4172/2324-8947.1000126

Nadler, A., \& Zak, P. J. (2016). Hormones and Economic Decisions. https://doi.org/10.1007/978-3-642-35923-1_3

Peterson, R. L. (2011). Neuroeconomics and Neurofinance. In Behavioral Finance: Investors, Corporations, and Markets. https://doi.org/10.1002/9781118258415.ch5

Simonsen, D. (2013). Hormones and behavior. Hormones and Behavior, 1-183. https://doi.org/10.2307/4510070

Stanton, S. J. (2016). The role of testosterone and estrogen in consumer behavior and social \& economic decision making: A review. Hormones and Behavior, 92, 155163. https://doi.org/10.1016/j.yhbeh.2016.11.006

Stanton, S. J. (2017, June 1). The role of testosterone and estrogen in consumer behavior and social \& economic decision making: A review. Hormones and Behavior, 
Vol. 92, pp. 155-163. https://doi.org/10.1016/j.yhbeh.2016.11.006

Stenstrom, E., \& Saad, G. (2011). Testosterone, Financial Risk-Taking, and Pathological Gambling. Journal of Neuroscience, Psychology, and Economics, 4(4), 254-266. https://doi.org/10.1037/a0025963

Bibliographic information of this paper for citing:

Nouraei, Maryam; Mohammadi Molgharni, Ataalah; Noravesh, Iraj \& Bahman Pour, Kaveh (2020). A Perusal of Managers' Optimism Pursuant to the Rate of Hormones in Blood.. Iranian Journal of Finance, 4(4), 28-43.

Copyright (c) 2020, Maryam Nouraei, Ataalah Mohammadi Molgharni, Iraj Noravesh and Kaveh Bahman Pour 
Seligman Optimism Questionnaire after confirmatory factor analysis

\begin{tabular}{|c|c|c|}
\hline $\begin{array}{l}\text { 1.The project you are in } \\
\text { charge of is very successful }\end{array}$ & $\begin{array}{c}\text { I closely monitor the } \\
\text { performance of everyone } \\
\text { while working. }\end{array}$ & $\begin{array}{l}\text { Everyone has put a lot of } \\
\text { time and energy into it. }\end{array}$ \\
\hline $\begin{array}{l}\text { 2- You reconcile with your } \\
\text { spouse (friend) after a fight. }\end{array}$ & I forgive him ( her) & I am usually large-hearted \\
\hline $\begin{array}{l}\text { 3.You, lose your friend's } \\
\text { house while driving. }\end{array}$ & I forgot to turn. & $\begin{array}{l}\text { My friend gave the address } \\
\text { badly. }\end{array}$ \\
\hline $\begin{array}{l}\text { 4. Your spouse (friend) } \\
\text { surprises you with a gift. }\end{array}$ & $\mathrm{S} / \mathrm{He}$ has done a great job. & $\begin{array}{l}\text { I also invited him/her to a } \\
\text { special place for dinner last } \\
\text { night. }\end{array}$ \\
\hline $\begin{array}{l}\text { 5.In the store, your credit } \\
\text { card is not valid. }\end{array}$ & $\begin{array}{l}\text { Sometimes I buy more than I } \\
\text { can afford }\end{array}$ & $\begin{array}{l}\text { Sometimes I forget to pay for } \\
\text { credit card recharge }\end{array}$ \\
\hline $\begin{array}{l}\text { 6.The value of your stock is } \\
\text { falling. }\end{array}$ & $\begin{array}{l}\text { I do not know much about } \\
\text { stocks and trading. }\end{array}$ & I did not choose good stocks. \\
\hline $\begin{array}{l}\text { 7-You will receive a great } \\
\text { reward. }\end{array}$ & I have solved a big problem. & $\begin{array}{l}\text { I am the best employee in the } \\
\text { company. }\end{array}$ \\
\hline $\begin{array}{l}\text { 8-You are asked to be a } \\
\text { project manager. }\end{array}$ & $\begin{array}{l}\text { I have recently successfully } \\
\text { completed a similar project }\end{array}$ & I am a good supervisor. \\
\hline $\begin{array}{l}\text { 9. Bosses give you little time } \\
\text { to complete the project, but } \\
\text { you finish it anyway. }\end{array}$ & I'm good at my job. & I am an effective person. \\
\hline $\begin{array}{l}\text { 10-You forgot your spouse } \\
\text { (friend) date of birth. }\end{array}$ & $\begin{array}{l}\text { I'm not good at remembering } \\
\text { birthdays }\end{array}$ & $\begin{array}{l}\text { My mind was preoccupied } \\
\text { with other things. }\end{array}$ \\
\hline $\begin{array}{c}\text { 11- You are in charge of the } \\
\text { department and you are } \\
\text { successful in your work. }\end{array}$ & $\begin{array}{c}\text { I have spent a lot of time and } \\
\text { energy on it }\end{array}$ & I work hard at everything. \\
\hline $\begin{array}{l}\text { 12- Your stock has risen in } \\
\text { price. }\end{array}$ & $\begin{array}{c}\text { This was my broker's } \\
\text { decision. }\end{array}$ & $\begin{array}{l}\text { I have a good and high-class } \\
\text { broker. }\end{array}$ \\
\hline $\begin{array}{l}\text { 13-You, miss an important } \\
\text { meeting. }\end{array}$ & $\begin{array}{l}\text { Sometimes I forget to look at } \\
\text { my calendar. }\end{array}$ & $\begin{array}{c}\text { Sometimes I do not have a } \\
\text { good memory }\end{array}$ \\
\hline $\begin{array}{l}\text { 14-You have been fined for } \\
\text { not paying taxes on time. }\end{array}$ & I always postpone this & $\begin{array}{l}\text { I have been lazy about this } \\
\text { year. }\end{array}$ \\
\hline
\end{tabular}

